\title{
SIDE-EFFECTS OF THIACETAZONE IN 143 CHILDREN
}

\author{
Save the Childrens Fund National Hospital, Masan
}

\author{
Dr. L.H. Hatcher
}

\section{Thiacetazone has been used at the Children's Wing} of the National Masan Hospital for in-patients and outpatients for 3 years. During the first years the choice of patients was confined to those between 12 and 16 years of age receiving treatment as in-patients. There were two distinct groups of children, those who had not received any previous anti-tuberculous therapy and a group who had received at least two of the standard drugs, streptomycin, PAS and isoniazid. The side effects noted were loss of appetite, nausea, vomiting, rashes and mental changes. The mental changes were probably due to the isoniazid not thiacetazone. (this was the opinion of the experts in London.)

The haemoglobin and white blood cell count were checked at two weekly intervals and there was no significant deterioration in either investigation. The liver function tests were not done because of the lack of laboratory facilities, there were no clinical signs indicating liver damage. All the children suffered from moderate advanced or far advanced pulmonary tuberculosis. During treatment there was radiologisal improvement in all the cases and the sputum converted to negative in all the cases who had not received previous treatment. The haemoglobin in all children was above $10 \mathrm{gms}$.

The dosage used was that recommended by the Medical Research Council each tablet contains:

thiacetazone $50 \mathrm{mgm}$

isoniazid $133 \mathrm{mgm}$.

\begin{tabular}{l|c|c}
\hline \hline Weight & thiacetazone in mgm & isoniazid in mgm \\
\hline Under $10 \mathrm{Kg}$ & $25 \mathrm{mgm}$ & $66 \mathrm{mgm}$ \\
$10-25 \mathrm{Kg}$ & 50 & 133 \\
$25-40 \mathrm{Kg}$ & 100 & 266 \\
Over $40 \mathrm{Kg}$ & 150 & 399 \\
\hline
\end{tabular}

There were 14 children between the age of 12 and 16 years who had received no previous anti-tuberculous drugs. 8 of these had side effects, 6 were gastro-intestinal and 2 developed rashes. One of the children who developed peraistent vomiting also became irrational in his behaviour. Treatment was discontinued and the symptoms disappeared. Another child had a severe rash which resolved after treatment with antihistamine.

Out of the 10 children who had received previous antituberculous drugs 7 developed rashes. One child developed an exfoloative dermatitis which did not respond to antihistamine. Thiacetazone was discontinued and the rash resolved spontaneously. Another child developed a severe irritating macula rash which resolved when thiacetazone was stopped. She was then desensitized by giving a small dose of thiacetazone and slowly increasing the dose to the therapeutic level. The full dose of isoniazid was maintained during the desensitisation.

In these two very small groups the development of a rash is more common if the patient has received previous anti-tuberculous therapy of the standard drugs. In a recent international study by the Medical Research Council the incidence of rashes was highest amongst the Chinese in Hong Kong.

It was decided early in 1966 to extend the use of thiacetazone to all age group irrespective of the type or site tuberculous lesion. i.e. primary pulmonary complex, segmental lesions, bone lesions, tuberculous cervical adenitis. Because of the larger number of children they had to be treated as out-patients and it was impossible to carry out any routine investigations other than bacteriology. Faced with this slight risk of lack of laboratory facilities it was decided to choose children who showed no ovious clinical signs of anaemia and whose 
general condition was fair to good. All new patients coming within this definition were given thiacetazone, 119 children were treated.

Side effects of 24 in-patients between $12 \& 16$ years of age

\begin{tabular}{l|c|c|c|c|c|c|c}
\hline \hline \multicolumn{1}{c|}{ Group } & $\begin{array}{c}\text { Loss of } \\
\text { appetite }\end{array}$ & Nausea & Vomiting & Rash & $\begin{array}{c}\text { No side } \\
\text { effect }\end{array}$ & Total & $\begin{array}{r}\% \text { side } \\
\text { effects }\end{array}$ \\
\hline No previous treatment & 0 & 3 & 3 & 2 & 6 & 14 & $57 \%$ \\
With previous treatment & 0 & 0 & 0 & 7 & 3 & 10 & $70 \%$ \\
\hline
\end{tabular}

Table 1

Side-Effects after Thiacetazone.

\begin{tabular}{l|c|c|c|c|c|c}
\hline \hline Age group & Loss of appetite & Nausea & Vomiting & Rash & No side effects & Total \\
\hline E0 $0-4$ & 6 & 0 & 0 & 0 & 6 & 12 \\
$5-9$ & 13 & 2 & 0 & 0 & 15 & 30 \\
$10-14$ & 1 & 0 & 0 & 0 & 3 & 6 \\
$15-16$ & 0 & 0 & 0 & 1 & 5 & 6 \\
Total & 20 & 2 & 0 & 3 & 29 & 54 \\
\hline
\end{tabular}

Table 2

Side-Effects Expressed as a Percentage

\begin{tabular}{c|c|c|c|c|c}
\hline \hline Age group & $\%$ Loss of Appetite & $\%$ Nausea & $\%$ Vomiting & $\%$ Rash & $\begin{array}{c}\text { Total number of } \\
\text { children }\end{array}$ \\
\hline $0-4$ & 26 & 0 & 0 & 0 & 23 \\
$5-9$ & 18 & 2 & 0 & 0 & 71 \\
$10-14$ & 5 & 0 & 0 & 10 & 20 \\
$15-16$ & 0 & 0 & 0 & 20 & 5 \\
\hline
\end{tabular}

Reports from other countries indicate that the side effects usually occur in the first two months of treatment therefore in this small study the side effect were noted during the first two months of treatment. The patients or parents were not asked directly about side effects but it was noted if they volunteered information spontaneously. The age grouping was 0-4 years, 5-9 years, 10-14 years and 15-16 years. Two groups of side effects were noted, gastro-intestinal and rashes. The gastro-intestinal symptoms were mild, either poor appetite with no gain in weight or loss of weight or nausea. The rashes appeared first on the hands and arms \& legs and spreading to the face and trunk. The rash was small irritating macule. In all cases the rash either disappeared spontaneously in one or two weeks or after an anti-histamine. The side effects were not severe enough for the parents to seek advice before the examination appointment. It was not necessary to discontinue treatment in any of the cases.

$19 \%$ of the children receiving thiacetazone therapy developed side effects of a mild nature.

The younger groups of children suffered from gastro- intestinal symptoms, 6 out of 23children under 4 years of age and 13 out of 71 children between 5 and 9 years had a loss of appetite. Only l child out of 20 in the 1014 years group complained of loss of appetite. In the whole serie 2 children between 5 and 9 years complained of nausea. The rashes only occured in the older age groups -2 children in the group 10-14 years and one child in the group 14-16 years.

There were no symptoms suggestive of liver or renal damage or neuro-logical symptoms.

Conclusion. -143 children were treated with thiacetazone

The frequency and severity of the side-effects during thiacetazone therapy seems to depend upon the general condition of the child. The two groups of in-patients suffered from moderately or far advanced pulmonary tuberculosis and they were generally ill and thin at the beginning of treatment. The out-patients had good or moderate general health. It also appears that rashes become more common with increasing age. It was necessary to discontinue treatment in 2 children, one for persistent vomiting and the other for a severe rash. 
결핵 및 호홉기질환 Vol. 15, No. 3, July, 1968

In my opinion thiacetazone is a safe drug for children whose general condition is moderately good, the sideeffects if any are mild.Children who are moderately or severely ill seem to develop side effects more frequently and of a more severe nature. In the present series this group of children were older than the moderately well children. In most cases the side effects do not warrant discontinuing therapy but the children should be examin- ed at intervals of at least two weeks during the first two months of treatment and monthly intervals after.

My impression is that children tolerate PAS better than thiacetazone gastro-intestinal side effects from PAS are rare in children.

Thiacetazon could be a valuable drug for contact cases and mild forms of tuberculous but there is a risk if it is used for severe infections in children.

\title{
（國交要約）
}

\section{3 名 小兒結核에 使用한 다이아세타존의 副作用}

\author{
國立馬山病院 小兒病棟
}

헷 차

小兒科 患者에 이 藥을 使用하여 보았다.

入院患者 24 名과 外來患者 119 名에 使用하여 副作用 을 觀察 하였다,

1. 入院患群 過去 治療歷이 없는 初治療 患者群 24 名에 게서 $57 \%$ 의 各種 副作用이 있고 過去 治療歷이 있는 患 者群 10 名에게서는 $70 \%$ 의 副作用이 있었다. 이 患者들 의 年齡은 12 歲에서 16 歲 兒童들이며 副作用으로는 惡 心 湢吐 發疹等이 있었다.

發疹은 過去 治療歷이 있는 患者群에게서 많이 發生 하였다.

2. 外來患者群 0 歲에서부터 16 歲까지의 여러가지 結 核性 疾患에 使用하여 보았다. 다이아세타존의 副作用 은 처음 2 個月內에 大部分 發生함으로 本研究도 처음 2 個月內의 副作用을 觀察하였으며, 檢查施設이 없어서 必要한 檢查는 하지 못했고 臨床的으로 貧血이 없는 般狀㦔가 좋은 兒童을 選擇 하였다.

副作用은 食箵不振이 0 歲一 4 歲群에서 $26 \% ， 5$ 歲-9 歲群에서 $18 \%, 10$ 歲-14 歲群에 $5 \%$ 나타났으며, 發㳂 은 10 歲-14 歲에서 10\% 15-16 藏에서 $20 \%$ 나타났다.
食忿不振은 어릴수록 많았으며 15 歲 이상은 없었고 發 疹은 反對로 어린아이에게는 볼 수 없고 年齢이 많을수

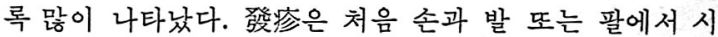
작하여 얼굴과 몸에 퍼져갔다. 外來患者 119 명중 $19 \%$ 가 副作用이 있었고 重한 副作用인 肝, 腎, 神經性 副作 用은 없었다. 投藥中斷한 患者는 頑固한 湢吐 1 명과 甚 한 發疹이 1 명 있었다.

筆者의 意見으로는 一般狀態가 좋은 兒童에게는 安全 하게 使用할 수 있으며, 中等度 또는 甚하게 않는 兒童 은 副作用이 많이 나타나며 또한 甚한 副作用을 일으킨 다.

大部分의 患者에서 副作用으로 藥을 中斷할 必要는 없 으며, 처음 2 個月內는 每 2 週마다, 그후는 每月 1 回 一般檢查를 하는것이 좋겠다. 小兒에서 파스 使用時 胃 腸障碍가 드믈며, 다이아세타존은 많다.

다이아세타존은 結核患者 接觸者와 輕한 結核에는 貴 重한 藥이다. 그러나 甚한 感染을 한 兒童은 危險하다.

$$
\text { <抄譯朴宗煜〉 }
$$

